\title{
Sudden Cardiac Death (SCD) - risk stratification and prediction with molecular biomarkers
}

\author{
Junaida Osman, Shing Cheng Tan, Pey Yee Lee, Teck Yew Low* (D) and Rahman Jamal
}

\begin{abstract}
Sudden cardiac death (SCD) is a sudden, unexpected death that is caused by the loss of heart function. While SCD affects many patients suffering from coronary artery diseases (CAD) and heart failure (HF), a considerable number of SCD events occur in asymptomatic individuals. Certain risk factors for SCD have been identified and incorporated in different clinical scores, however, risk stratification using such algorithms is only useful for health management rather than for early detection and prediction of future SCD events in high-risk individuals. In this review, we discuss different molecular biomarkers that are used for early detection of SCD. This includes genetic biomarkers, where the majority of them are genomic variants for genes that encode for ion channels. Meanwhile, protein biomarkers often denote proteins that play roles in pathophysiological processes that lead to CAD and HF, notably (i) atherosclerosis that involves oxidative stress and inflammation, as well as (ii) cardiac tissue damage that involves neurohormonal and hemodynamic regulation and myocardial stress. Finally, we outline existing challenges and future directions including the use of OMICS strategy for biomarker discovery and the multimarker panels.
\end{abstract}

Keywords: sudden cardiac death (SCD), coronary artery disease (CAD), heart failure (HF), coronary heart disease (CHD), cardiovascular disease (CVD), biomarker

\section{Background}

The heart serves as a biological pump that circulates blood throughout our bodies and thus supplying us with oxygen and nutrients. Within the heart, a heartbeat is first initiated by the sinoatrial (SA) node that releases electrical stimuli. These stimuli traverse the atrioventricular (AV) nodes, the bundle of His, subsequently into the bundle branches and Purkinje fibres, causing the contractions of heart cells called cardiomyocytes. However, these electrical stimuli can sometimes become disorganized, due to ventricular tachycardia or ventricular fibrillation [1]. Irregular cardiac activities restrict blood supply to the brain, causing rapid death of brain cells and leading to sudden cardiac death (SCD) $[2,3]$. Globally, SCD accounts for 4-5 million deaths per year [4], and is strongly linked to coronary artery diseases (CAD), especially myocardial infarction (MI) [5]. Other

\footnotetext{
* Correspondence: lowteckyew@ppukm.ukm.edu.my

UKM Medical Molecular Biology Institute (UMBI), Universiti Kebangsaan Malaysia, Kuala Lumpur, Malaysia
}

causes for SCD include cardiomyopathies and inherited channelopathies [6].

\section{Prevention and treatment of SCD}

To prevent SCD, implantable cardioverter defibrillator (ICD) is used prophylactically in individuals with existing conditions of cardiomyopathy and inherited arrhythmias. Upon detecting an abnormal heart rhythm, ICD delivers an electric shock to restore normal heartbeats. However, the survival benefits of the ICDs are limited as only 20 $30 \%$ of patients with ICD receive appropriate therapy [7]. On the other hand, patients with history of MI are recommended to consume beta-blockers, which reduces recurrent MI and angina, but not mortality [8]. Targeting resistant hyper-triglyceridemia is another option. Current European and US guidelines target low-density lipoprotein cholesterol (LDL-C) levels as the primary approach for treatment [9]. However, it was shown that the risk of cardiovascular disease (CVD) increase with excess levels of triglycerides (TG), even in patients with optimally managed LDL-C levels [10]. 


\section{Risk factors for SCD}

Stratification of clinical risks, including that of SCD, is an important step in effective health management (Fig. 1). Since CAD and heart failure (HF) underly a significant majority of SCD incidence, risk factors for CAD and HF are accepted as predictors for SCD-related deaths and allcause mortality [11]. In fact, these risk factors, including (i) increased age, (ii) male gender, (iii) cigarette exposure, (iv) hypertension, (v) obesity, (vi) hypercholesterolemia, (vii) diabetes mellitus and (viii) family history have been incorporated into the US-based Framingham Risk Score and Europe-based HeartScore for estimating cardiovascular risks [12, 13]. Apart from those mentioned, other SCD-related risk factors that can be evaluated in clinical laboratories include (i) left ventricle (LV) dysfunction, (ii) history of heart failure (HF), (iii) left ventricular hypertrophy, (iv) poor heart functional status, (v) elevated heart rate and (vi) abnormal electrocardiogram (ECG). Among these, left ventricular ejection fraction (LVEF) measures the blood volume pumped out of the left ventricle using echocardiogram, nuclear magnetic imaging (MRI) or nuclear medicine scan [14]. LVEF classifies HF into (i) reduced (LVEF < 40\%), (ii) preserved (LVEF > 50\%) and (iii) intermediate (LVEF $\sim 40-49 \%$ ) categories [15]. Meanwhile, ECG measures the rate and rhythm of heartbeats, the size and position of the heart chambers, or detect any injuries to the heart muscle or conduction system. Abnormal ECGs, such as prolonged QT interval, Tpeak-Tend interval and $\mathrm{T}$-wave alternans have been proposed as risk markers $[16,17]$. Nevertheless, besides the lack of consistent association between QT interval prolongation and total or cardiovascular mortality in population-based studies [18], these markers also preclude high-risk individuals without CAD symptoms [7].

\section{Detecting and screening SCD with molecular biomarkers}

The flow of genetic information from genes to RNAs, proteins and metabolites together form the molecular layers that interact with the environment to contribute to biological traits including disease phenotypes [19]. Naturally, these biomolecules are appropriate candidates for "biomarkers". Biomarkers are objective indicators of normal biological processes, pathogenic processes or pharmacological responses [20]. Ideally, a biomarker should be: (i) sensitive, (ii) specific, (iii) cost-effective, (iv) easily obtainable and (v) non-invasive [21]. Importantly, it should also be (vi) quantifiable, correlate well with the severity of disease conditions and (vii) able to offer early detection.

\section{Genetic biomarkers}

Since many SCD cases are heritable, early genetic studies apply the candidate gene approach to identify potentially meaningful genomic variants that are involved in various predisposing cardiac conditions, such as the long QT syndrome, Brugada syndrome, or cardiomyopathies. Genetic markers are effective for screening high-penetrance genome variants that predispose otherwise asymptomatic

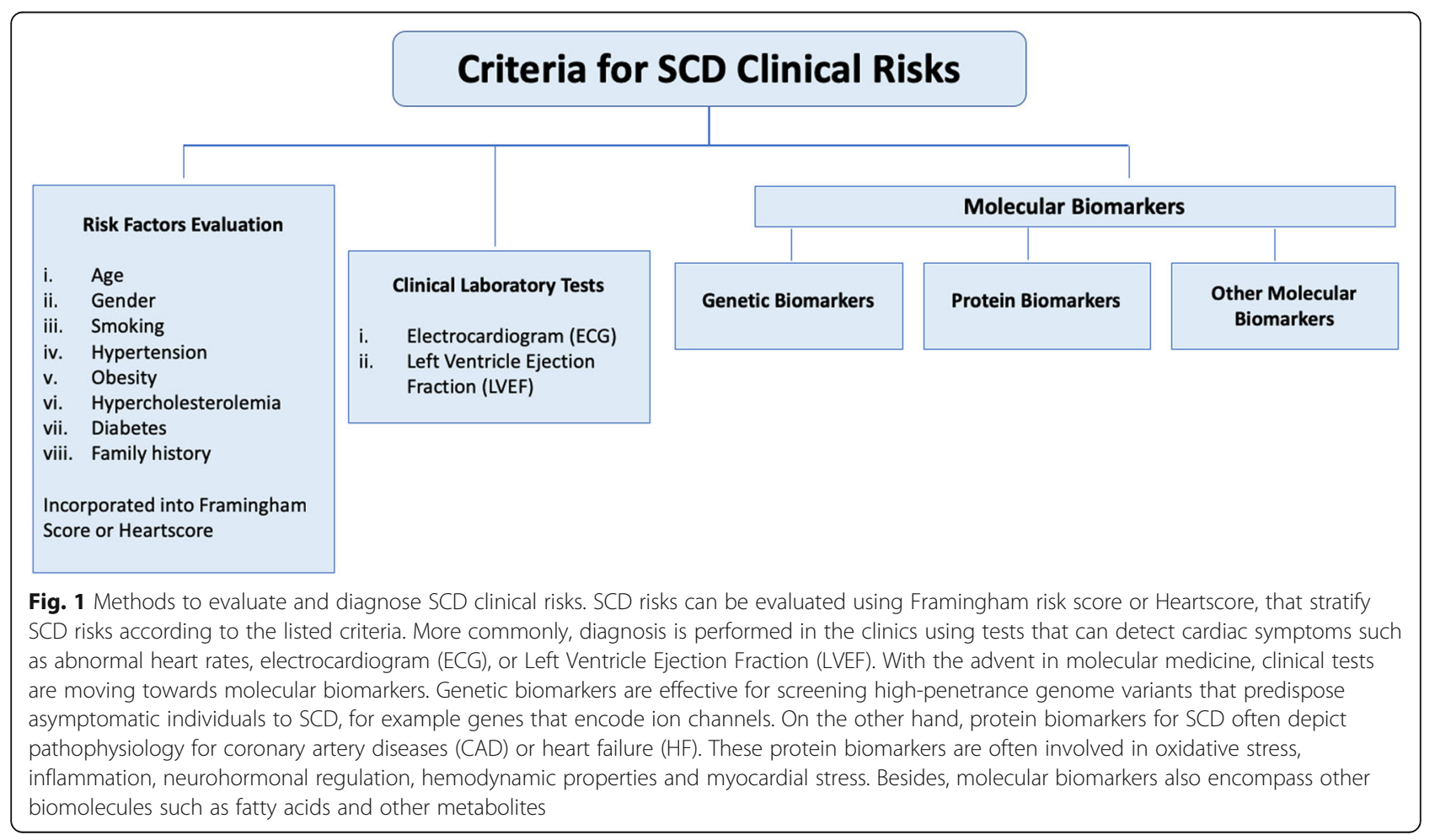


Table 1 List of genetic biomarkers associated with SCD

\begin{tabular}{|c|c|c|c|c|c|}
\hline Gene & Putative gene function & Association with SCD & SNP/mutation & $\begin{array}{l}\text { Strength } \\
\text { of } \\
\text { evidence }^{a}\end{array}$ & Ref \\
\hline \multirow[t]{3}{*}{ SCN5A } & \multirow[t]{3}{*}{$\begin{array}{l}\text { Encodes a subunit of the cardiac voltage-gated sodium channel } \\
\text { (Nav1.5) }\end{array}$} & \multirow[t]{3}{*}{ Variants were associated with SCD } & $\begin{array}{l}\text { rs7626962 } \\
\text { (p.Ser1103Tyr) }\end{array}$ & \multirow[t]{3}{*}{++} & {$[25]$} \\
\hline & & & rs11720524 & & [22] \\
\hline & & & rs41312391 & & [26] \\
\hline \multirow[t]{4}{*}{$\mathrm{KCNH} 2$} & \multirow[t]{4}{*}{$\begin{array}{l}\text { Encodes the } K_{v} 11.1 \text { channel that regulates the rapid component } \\
\text { of the delayed rectifier potassium current }\end{array}$} & \multirow[t]{2}{*}{ Variants were associated with SCD } & $\begin{array}{l}\text { rs199472830 } \\
\text { (p.Phe29Leu) }\end{array}$ & \multirow[t]{2}{*}{+} & [30] \\
\hline & & & $\begin{array}{l}\text { rs199472882 } \\
\text { (p.Pro297Ser) }\end{array}$ & & [30] \\
\hline & & \multirow[t]{2}{*}{$\begin{array}{l}\text { Variants were associated with } \\
\text { probable SCD cases }\end{array}$} & $\begin{array}{l}\text { rs199472918 } \\
\text { (p.Leu552Ser) }\end{array}$ & \multirow[t]{2}{*}{+} & [31] \\
\hline & & & $\begin{array}{l}\text { rs36210422 } \\
\text { (p.Arg176Trp) }\end{array}$ & & [31] \\
\hline \multirow[t]{2}{*}{ KCNQ1 } & \multirow[t]{2}{*}{$\begin{array}{l}\text { Encodes the } K_{v} 7.1 \text { channel that regulates the slow delayed } \\
\text { rectifier current }\end{array}$} & Variant was associated with SCD & $\begin{array}{l}\text { rs120074178 } \\
\text { (p.Arg190Trp) }\end{array}$ & + & [30] \\
\hline & & $\begin{array}{l}\text { Variant was associated with an } \\
\text { increased risk of SCD }\end{array}$ & rs2283222 & + & [32] \\
\hline RYR2 & $\begin{array}{l}\text { Encodes calcium channel involved in the regulation of calcium } \\
\text { ion release from the sarcoplasmic reticulum }\end{array}$ & $\begin{array}{l}\text { Variant was associated with an } \\
\text { increased risk of SCD }\end{array}$ & $\begin{array}{l}\text { rs3766871 } \\
\text { (p.Gly1886Ser) }\end{array}$ & ++ & [23] \\
\hline MYBPC3 & $\begin{array}{l}\text { Encodes cardiac myosin binding protein } \mathrm{C} \text { required for normal } \\
\text { cardiac function }\end{array}$ & $\begin{array}{l}\text { Variant was associated with an } \\
\text { increased risk of SCD }\end{array}$ & p.F305Pfs 27 & + & [34] \\
\hline ACE & $\begin{array}{l}\text { Encodes angiotensin converting enzyme that catalyzes the } \\
\text { conversion of angiotensin I to angiotensin II and the inactivation } \\
\text { of bradykinin via the kallikrein-kininogen system }\end{array}$ & $\begin{array}{l}\text { Variant was associated with an } \\
\text { increased risk of SCD }\end{array}$ & $\begin{array}{l}\text { DD genotype or } \\
\text { D allele }\end{array}$ & + & [35] \\
\hline \multirow[t]{3}{*}{ PKP2 } & \multirow{3}{*}{$\begin{array}{l}\text { Encodes plakophilin } 2 \text { which is responsible for linking cadherins } \\
\text { to intermediate filaments in the cytoskeleton }\end{array}$} & \multirow{3}{*}{$\begin{array}{l}\text { Variants were associated with } \\
\text { arrhythmia disorder and risk of SCD }\end{array}$} & Q59L & \multirow[t]{3}{*}{+} & \multirow[t]{3}{*}{ [31] } \\
\hline & & & Q62K & & \\
\hline & & & N613K & & \\
\hline \multirow[t]{8}{*}{ DSP } & \multirow[t]{8}{*}{$\begin{array}{l}\text { Encodes desmoplakin that functions to maintain structure } \\
\text { integrity }\end{array}$} & \multirow{8}{*}{$\begin{array}{l}\text { Variants were associated with sudden } \\
\text { unexplained nocturnal death } \\
\text { syndrome (SUNDS) }\end{array}$} & $\begin{array}{l}\text { rs188516326 } \\
\text { (p.Q90R) }\end{array}$ & \multirow[t]{8}{*}{+} & \multirow[t]{8}{*}{ [36] } \\
\hline & & & $\begin{array}{l}\text { rs116888866 } \\
\text { (p.R2639Q) }\end{array}$ & & \\
\hline & & & $\begin{array}{l}\text { rs200476515 } \\
(p . R 315 C)\end{array}$ & & \\
\hline & & & $\begin{array}{l}\text { rs569786610 } \\
\text { (p.E1357D) }\end{array}$ & & \\
\hline & & & $\begin{array}{l}\text { rs185367490 } \\
\text { (p.N1234S) }\end{array}$ & & \\
\hline & & & $\begin{array}{l}\text { rs184154918 } \\
\text { (p.R1308Q) }\end{array}$ & & \\
\hline & & & $\begin{array}{l}\text { rs181378432 } \\
\text { (p.T2267S) }\end{array}$ & & \\
\hline & & & $\begin{array}{l}\text { novel } \\
\text { (p.D2579H) } \\
\text { (p.l125F) } \\
\text { (p.D521A) }\end{array}$ & & \\
\hline
\end{tabular}

aStrength of evidence was rated as " + ": weak, " ++ ": medium and " +++ ": strong based on number of published findings supporting significant correlation of a particular biomarker with SCD, sample size and clinical validity

individuals to SCD. Early genetic studies had identified such variants by applying the candidate gene approach, whereby candidate genes are first selected based on the functions of wild-type gene products or the biochemical pathway involved in diseases. Association studies are then performed to evaluate variation in the sequences of selected genes predicted to be involved in pathogenesis.

One biomarker that was discovered with this approach is SCN5A, which encodes the alpha subunit of the voltage-gated sodium channel $\mathrm{Na}_{\mathrm{v}} 1.5$ [22-24]. $\mathrm{Na}_{\mathrm{v}} 1.5$ 
regulates the influx of sodium ion, and thus the initiation and propagation of action potentials of the heart. Any variations or mutations in SCN5A that affect the structure, function or expression of the sodium channel cause a delayed or persistent entry of sodium ions across the cell membrane, leading to arrhythmogenic syndromes and $\mathrm{SCD}$. Among the SCD-related genetic variations that have been identified in the SCN5A gene include: (i) rs7626962 (p.Ser1103Tyr), which causes an amino acid substitution in a conserved sequence between domains II and III of $\mathrm{Na}_{\mathrm{v}} 1.5$ [25]; (ii) rs11720524, which has been predicted to disrupt a transcription factor binding site of the gene [22]; and (iii) rs41312391, that modulates the expression of an adjacent gene that is implicated in the regulation of histone deubiquitinating complexes [26].

Potassium channels play a role in the repolarization of the cardiac action potential [27, 28], and anomalies in the rate of cardiac repolarization can lead to SCD [29]. Notably, $K C N H 2$ which encodes the $\mathrm{K}_{\mathrm{v}} 11.1$ channel that regulates the rapid component of the delayed rectifier potassium current; and KCNQ1 which encodes the $\mathrm{K}_{\mathrm{v}} 7.1$ channel that regulates the slow delayed rectifier current are important targets. Several $K C N H 2$ and $K C N Q 1$ mutations tare present in long QT syndrome and were documented in SCD [30]. These mutations include the rs199472830 (p.Phe29Leu) and rs199472882 (p.Pro297Ser) mutations of $K C N H 2$, as well as the rs120074178 (p.Arg190Trp) mutation of KCNQ1. Besides, a study in the Finnish population reveals the occurrence of KCNH2 rs199472918 (p.Leu552Ser) and rs36210422 (p.Arg176Trp) mutations among three probable SCD cases, although statistical analysis suggested a lack of significant association between the mutations and SCD risk [31]. In addition, Albert et al. showed that the rs2283222 variant of KNCQ1 gene was significantly associated with an increased risk of SCD [32].

Calcium channels are involved in the excitationcontraction coupling (ECC) process. The cardiac ryanodine receptor (RyR2) is a calcium channel that regulates calcium ion release from the sarcoplasmic reticulum. Activation of RyR2 facilitates binding of calcium ions to contractile proteins of the heart muscle, which activates systolic contraction of the cardiac myocytes [33]. To

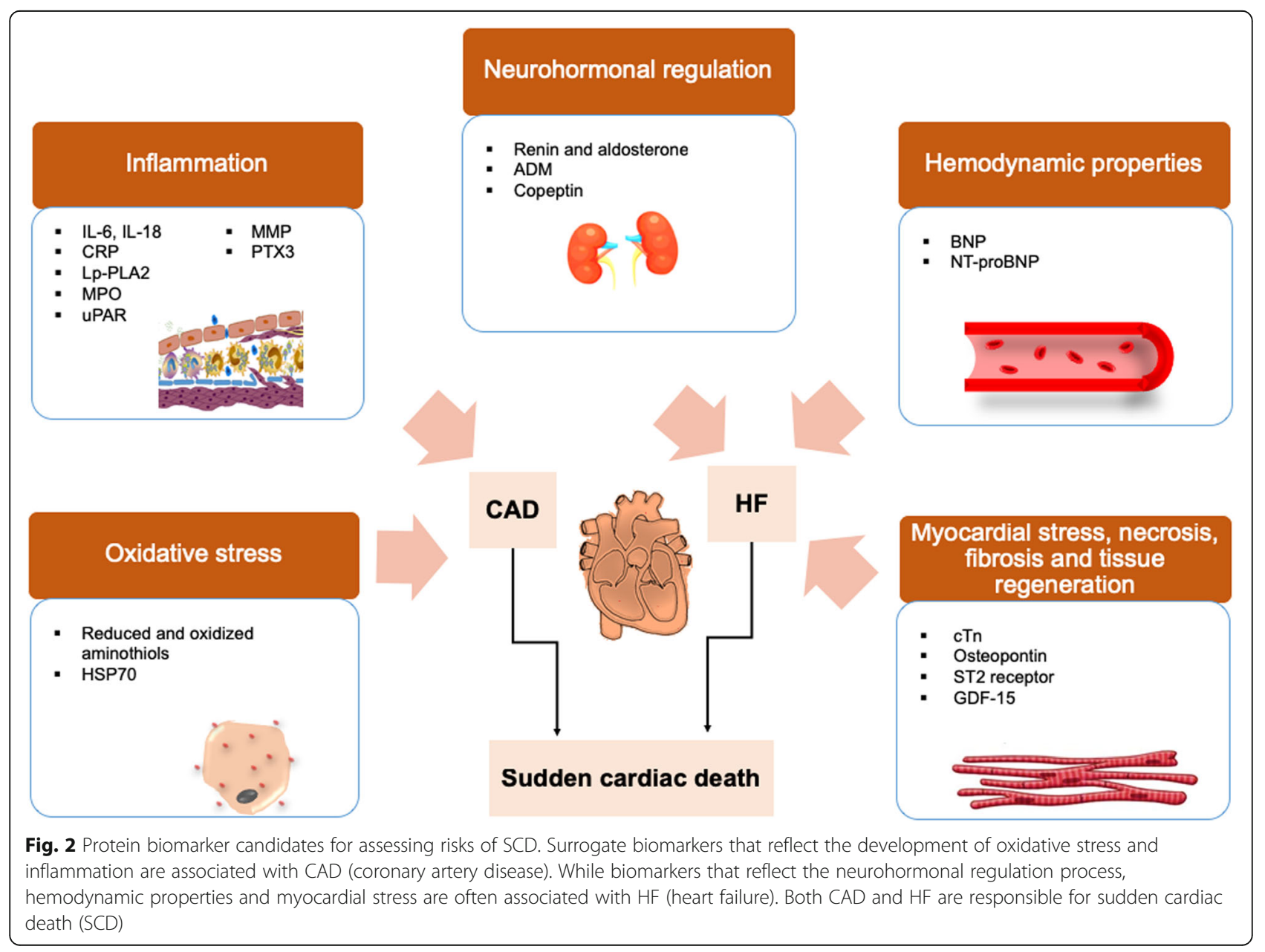


maintain a regular heartbeat, the activity of RyR2 must be tightly-regulated. Abnormal leak of calcium ions through dysregulated RyR2 can cause an altered membrane potential, which in turn introduce irregular contractile and electrical activity, resulting in cardiac arrhythmia and possibly, SCD [33]. A prominent RYR2 mutation that has been implicated in SCD is rs3766871 (p.Gly1886Ser), which is present in high prevalence in a molecular autopsy study involving 173 SCD cases, whereby rs3766871 has been demonstrated to result in an increased calcium ion oscillation in the cell and has been postulated to cause diastolic calcium ion leak [23]. As such, it is not surprising that the rs3766871 variant was found to be associated with an almost 2-fold increased risk of SCD.

Mutations in other cardiac-related genes have also been implicated in SCD. These include: $M Y B P C 3$, which encodes cardiac myosin binding protein $C$ [34]; $A C E$, which encodes angiotensin converting enzyme [35]; PKP2, which encodes plakophilin 2 [31]; DSP, which encodes desmoplakin [36]. Many of these mutations are rare in the general population, but can contribute to SCD risk in a highly penetrant manner. A collection of genetic biomarkers together with the strength of evidence to indicate their correlation with SCD is shown in Table 1.

Nowadays, researchers have gradually switched to genome-wide association studies (GWAS) to validate these variants, and identify novel ones [24, 37]. Nevertheless, different GWAS studies are often inconsistent, which can be due to the heterogeneity in case definitions [38]. To address this inconsistency, a meta-analysis was conducted to discover potential genetic biomarkers of SCD with high statistical power, and found that the $B A Z 2 B$ gene locus was associated with a 1.92-fold increased risk of SCD [37]. Recently, a gene panel targeting 174 expertly-selected genes implicated in inherited cardiac conditions (ICCs) has become commercially available [39]. As ICCs predispose healthy individuals to sudden death, screening SCD cases with this gene panel facilitates high-throughput identification of deleterious variants that underlie SCD. This gene panel has been used in conjunction to another gene panel to perform a molecular autopsy on 302 idiopathic SCD cases (however, only 77 of the 174 genes were analyzed) [40]. After applying robust filtering strategies and stringent criteria for variant classification, it was found that a clinically actionable pathogenic or likely pathogenic variant was present in $13 \%$ of the cases. Interestingly, the majority of the pathogenic or likely pathogenic variants resided in SCN5A, KCNH2, KCNQ1 and RYR2 genes as described earlier, which further established these genes as genetic biomarkers of SCD.

\section{Protein biomarkers}

Proteins are routinely used as analytes in clinical diagnostics. Biofluids, especially plasma and serum are rich and non-invasive sources of circulating proteins that can provide quantifiable readout as biomarkers. Protein biomarkers for cardiac disorders often reflect the underlying pathophysiological processes in CAD or HF, two major causes of SCD (Fig. 2). These pathophysiological processes include (i) oxidative stress, (ii) inflammation that subsequently leads to atherosclerosis, (iii) neurohormonal regulation, (iv) hemodynamic properties, (v) myocardial stress, (vi) necrosis, (vii) fibrosis and (viii) tissue regeneration $[41,42]$.

\section{Atherosclerosis and CAD}

A major cause of CAD is atherosclerosis, whereby the inside of an artery becomes narrowed due to build-up of plaque. Initially, low-density lipoproteins (LDL) drives atherosclerosis by invading the endothelia of blood vessels, subsequently become trapped in the sub-endothelial space and oxidized by reactive oxygen species (ROS). Oxidized LDLs (oxLDLs) initiate a series of events leading to inflammatory responses [43], build-up of vulnerable plaques, platelet activation, plaque instability, erosion and rupture.

\section{Oxidative stress biomarkers}

As such, oxidative stress represents an initiating event in CAD. It can be assessed by quantifying the levels of plasma aminothiol antioxidants such as cysteine and glutathione and their oxidized counterparts, i.e. cystine and glutathione disulfide [44]. High cystine and low glutathione levels are associated with increased mortality in subjects with CAD [45]. Heat shock proteins (HSPs) are upregulated during oxidative stress [46]. Its levels were demonstrated to be significantly lower in CAD patients, and inversely proportional to the degree of atherosclerosis [47]. However, in a study of 3415 patients with suspected or known CAD undergoing cardiac catheterization, elevated HSP70 levels correlated with increased risk of cardiac death even after adjustment for clinical variables and hsCRP [48].

\section{Inflammation biomarkers}

During atherosclerotic development, following oxidative stress, accumulating oxLDLs recruit monocytes to its residing sub-endothelial space. These transmigrated monocytes subsequently differentiate into macrophages, proliferate locally and ingest oxLDLs, turning into "foam cells" slowly [49]. These macrophages and endothelial cells then release pro-inflammatory cytokines such as interleukin-1 (IL-1), IL-6, IL-8, IL-10 and IL-18 that are involved in T-cell activation [50]. Among these interleukins, IL- 6 and IL-18 are established as inflammatory 
biomarkers that are associated with CAD. In the PRIME study that involved 10,000 asymptomatic European middle-aged men, IL-6 was associated with an increased risk of SCD [51]. Zhao et al. evaluated the relationship of IL-6 with the extent and severity of CAD using coronary computed tomography angiography (CCTA) and detected the association of high IL-6 levels with major adverse cardiac events (MACE) and higher atherosclerotic burden [52]. Cainzos-Achirica et al. explored the prognostic value of IL-6 for the prediction of atherosclerotic cardiovascular disease (ASCVD) events, HF, and other chronic diseases in 6617 participants and concluded that IL-6 is strongly and independently associated with ASCVD events, HF, and all-cause mortality, particularly among statin users [53]. IL-18 is another promising prognostic marker for CAD [54]. Opstad at al. investigated 1001 patients with angiographically verified stable CAD by measuring their circulating IL-18 and IL12 with ELISA methods [55]. After a 2-year follow-up, 100 cardiovascular endpoints were recorded whereby subjects with simultaneous levels in upper tertiles of both markers were at higher risk of cardiovascular events.

C-reactive protein (CRP) is an acute-phase protein that is secreted by the liver in response to circulating levels of IL-6, IL-1 and TNF- $\alpha$ during the atherosclerotic process [56]. CRP is capable of activating the complement system by binding to phosphocholine molecules on the surface of dead or dying cells [57]. It is also a biomarker for CAD and SCD and can be measured with a high sensitivity CRP (hs-CRP) assay at sub-clinical levels (0.5 to $10 \mathrm{mg} / \mathrm{L}$ ). The Physicians' Health Study showed that CRP levels were an independent risk factor for SCD in males after correcting for potential confounders in the general population [58]. In the JUPITER study, randomized statin therapy was given to asymptomatic individuals who manifested elevated levels of hsCRP and LDL, and these individuals experienced $47 \%$ reduction in the risk of non-fatal MI, stroke, and cardiovascular death [59]. The BARI-2D trial also discovered a correlation between elevated CRP levels and cardiovascular events [60]. However, there were no observed associations between CRP levels and SCD in the female-based Nurses Health Study and the male-based PRIME study [51, 61].

Lipoprotein-associated phospholipase A2 (Lp-PLA2) is an enzyme that co-travels with circulating LDL, and hydrolyzes oxidized phospholipids in LDL. Lp-PLA2 produces lysophosphatidylcholine and oxidized non-esterified fatty acids, both being bioactive lipid mediators that elicit inflammatory responses [62]. Lp-PLA2 levels were found to independently predict the presence of CAD in the general population, after adjusting for hs-CRP and B-type natriuretic peptide (BNP) [63, 64]. Another oxidaive- stress-related enzyme, myeloperoxidase (MPO), a heme peroxidase, participates in LDL oxidation mediated by radical 1e-oxidation and non-radical 2e-oxidation [65]. Detection, quantification and imaging of MPO mass and activity are useful in cardiac risk stratification [66]. Meanwhile, urokinase-type plasminogen activator receptor (uPAR) is a GPI-anchored membrane protein that, during inflammation, becomes shedded from cell membrane and forms soluble uPAR (suPAR) [67]. The levels of plasma suPAR were shown to correlate with pro-inflammatory markers and even outperform CRP at prognosticating CVD $[68,69]$. Another protein, pentraxin-3 (PTX3) is released upon primary inflammatory signals [70] and has been implicated as an inflammatory biomarker for CAD [71]. In two independent clinical trials (CORONA and GISSI-HF) enrolling patients with chronic HF, PTX3 was consistently associated with adverse outcomes [72]. Finally, matrix metalloproteinases (MMP) are implicated in plaque formation and rupture, leading to coronary occlusion [73]. Individuals with acute coronary syndrome and CAD were shown to possess elevated levels of MMP-1, $2,-8$ and -9 in their plasma $[74,75]$.

\section{Heart failure (HF) and SCD events}

Besides CAD, another heart condition that can potentially lead to SCD is heart failure (HF). HF occurs when the heart is unable to pump sufficient blood to supply nutrients and oxygen. In HF, the reduction in cardiac output can be attributed to a cardiac acute injury, a long-standing haemodynamic overload; or genetic variations that disrupt contractile function [76]. The reduction in blood circulation is sensed by peripheral arterial baroreceptors that activate compensatory mechanisms to maintain cardiovascular homeostasis. These compensatory mechanisms include (i) the renin-angiotensin-aldosterone system (RAAS), which maintain cardiac output through increased retention of salt and water, peripheral arterial vasoconstriction and increased contractility; (ii) activation of the adrenergic (sympathetic) nervous system (ANS) to increase heart rate, cardiac contractility and accelerate cardiac relaxation; (iii) secretion of inflammatory mediators and (iv) cardiac repair and remodelling. Certain proteins that are involved in these compensatory mechanisms have been demonstrated to be predictive of SCD.

\section{Neurohormonal biomarkers}

Elevated renin and aldosterone levels were found to be associated with HF and SCD in the LURIC study [77, 78]. Besides, increased aldosterone levels were associated with a higher risk of cardiac arrest in the post-ST-segment elevation MI population [79]. The adrenergic nervous system (ANS) system can also become dysregulated in HF. For example, adrenomedullin (ADM) is a peptide 
Table 2 Summary of protein biomarkers related to various pathophysiological processes that are associated with cardiovascular disease (CVD)

\begin{tabular}{|c|c|c|c|c|}
\hline Process & Biomarkers & Association with CVD & $\begin{array}{l}\text { Strength } \\
\text { of } \\
\text { evidence }^{a}\end{array}$ & Ref \\
\hline \multirow[t]{3}{*}{ Oxidative stress } & $\begin{array}{l}\text { Reduced (cysteine and glutathione) and } \\
\text { oxidized (cystine and glutathione disulphide) } \\
\text { aminothiols }\end{array}$ & $\begin{array}{l}\text { High cystine (oxidized) and low glutathione (reduced) } \\
\text { levels were associated with higher mortality in patients } \\
\text { with CAD }\end{array}$ & ++ & {$[45]$} \\
\hline & \multirow[t]{2}{*}{ Heat shock protein 70 (HSP70) } & High levels of HSP70 were associated with low CAD risk & + & {$[47]$} \\
\hline & & $\begin{array}{l}\text { High HSP70 levels were associated with increased risk of } \\
\text { cardiac death }\end{array}$ & & {$[48]$} \\
\hline \multirow[t]{12}{*}{ Inflammation } & \multirow[t]{5}{*}{ Interleukin (IL) such as IL-6 and IL-18 } & $\begin{array}{l}\text { Higher IL-6 levels were associated with SCD and was an } \\
\text { independent predictor of sudden death }\end{array}$ & +++ & {$[51]$} \\
\hline & & $\begin{array}{l}\text { High levels of IL-6 were associated with increased burden } \\
\text { of atherosclerosis and higher risk of major adverse cardiac } \\
\text { events (MACE) risk }\end{array}$ & & {$[52]$} \\
\hline & & Higher IL-6 levels were associated with atherosclerotic car & & {$[53]$} \\
\hline & & $\begin{array}{l}\text { diovascular disease (ASCVD) events, heart failure (HF) and } \\
\text { mortality }\end{array}$ & & [55] \\
\hline & & $\begin{array}{l}\text { Higher levels of IL-18 and IL-12 were associated with in } \\
\text { creased risk of cardiovascular events }\end{array}$ & & \\
\hline & \multirow[t]{2}{*}{ C-reactive protein (CRP) } & $\begin{array}{l}\text { High CRP levels were associated with greater mortality } \\
\text { and risk of cardiovascular disease }\end{array}$ & ++ & {$[60]$} \\
\hline & & $\begin{array}{l}\text { CRP levels were not significantly associated with sudden } \\
\text { death and SCD risk }\end{array}$ & & $\begin{array}{l}{[51,} \\
61]\end{array}$ \\
\hline & $\begin{array}{l}\text { Lipoprotein-associated phospholipase A2 (Lp- } \\
\text { PLA2) }\end{array}$ & $\begin{array}{l}\text { Higher Lp-PLA2 levels were associated with increased risk } \\
\text { of coronary heart disease and was an independent pre } \\
\text { dictor of CHD events }\end{array}$ & + & $\begin{array}{l}{[63,} \\
64]\end{array}$ \\
\hline & Myeloperoxidase (MPO) & $\begin{array}{l}\text { MPO levels were associated with the incidence and } \\
\text { severity of CAD }\end{array}$ & + & {$[66]$} \\
\hline & $\begin{array}{l}\text { Urokinase-type plasminogen activator } \\
\text { receptor (UPAR) }\end{array}$ & $\begin{array}{l}\text { High suPAR levels were associated with increased risk of } \\
\text { CVD }\end{array}$ & ++ & $\begin{array}{l}{[68,} \\
69]\end{array}$ \\
\hline & Matrix metalloproteinases (MMP) & $\begin{array}{l}\text { Higher levels of MMP-1, }-2,-8 \text { and }-9 \text { were associated } \\
\text { with acute coronary syndromes and CAD }\end{array}$ & + & $\begin{array}{l}{[74,} \\
75]\end{array}$ \\
\hline & Pentraxin-3 (PTX3) & $\begin{array}{l}\text { PTX3 was associated with higher risk of mortality in } \\
\text { patients with chronic heart failure }\end{array}$ & + & {$[72]$} \\
\hline \multirow[t]{4}{*}{$\begin{array}{l}\text { Neurohormonal } \\
\text { regulation }\end{array}$} & Renin and aldosterone & $\begin{array}{l}\text { Higher plasma renin and aldosterone levels were } \\
\text { associated with increased risk of cardiovascular mortality } \\
\text { and adverse outcome in ST-elevation myocardial infarction } \\
\text { (STEMI) }\end{array}$ & +++ & $\begin{array}{l}{[77-} \\
79]\end{array}$ \\
\hline & \multirow[t]{2}{*}{ Adrenomedullin (ADM) } & High ADM levels were associated with heart failure & ++ & $\begin{array}{l}{[81,} \\
82]\end{array}$ \\
\hline & & $\begin{array}{l}\text { Mid-regional pro-atrial natriuretic peptide (MR-proANP) } \\
\text { demonstrated diagnostic and prognostic utility in patients } \\
\text { with acute heart failure (AHF) }\end{array}$ & & $\begin{array}{l}{[80,} \\
84]\end{array}$ \\
\hline & Copeptin & $\begin{array}{l}\text { High copeptin levels were associated with increased } \\
\text { mortality, readmissions, and emergency department visits } \\
\text { in patients with acute heart failure as well as excess } \\
\text { mortality in patients with chronic HF }\end{array}$ & + & $\begin{array}{l}{[86,} \\
87]\end{array}$ \\
\hline \multirow[t]{3}{*}{$\begin{array}{l}\text { Hemodynamic } \\
\text { properties }\end{array}$} & \multirow{3}{*}{$\begin{array}{l}\text { Natriuretic peptides (NP), i.e. (B-type natriuretic } \\
\text { peptide) BNP or (N-terminal pro B-type natri- } \\
\text { uretic peptide) NT-proBNP }\end{array}$} & $\begin{array}{l}\text { Higher NT-proBNP levels were associated with increased } \\
\text { risk of SCD }\end{array}$ & +++ & $\begin{array}{l}{[61,} \\
89]\end{array}$ \\
\hline & & $\begin{array}{l}\text { High BNP levels were an independent predictor of sudden } \\
\text { death in patient with chronic heart failure }\end{array}$ & & {$[90]$} \\
\hline & & $\begin{array}{l}\text { High BNP levels were associated with higher risk of death/ } \\
\text { mortality in patients with acute myocardial infarction }\end{array}$ & & [91] \\
\hline $\begin{array}{l}\text { Myocardial stress, } \\
\text { necrosis, fibrosis and } \\
\text { tissue regeneration }\end{array}$ & Cardiac troponins (cTn) & $\begin{array}{l}\text { High levels of cTn were associated with the risk of death } \\
\text { from cardiovascular causes, myocardial infarction, stroke or } \\
\text { heart failure }\end{array}$ & +++ & $\begin{array}{l}{[92-} \\
96]\end{array}$ \\
\hline
\end{tabular}


Table 2 Summary of protein biomarkers related to various pathophysiological processes that are associated with cardiovascular disease (CVD) (Continued)

\begin{tabular}{|c|c|c|c|c|}
\hline Process & Biomarkers & Association with CVD & $\begin{array}{l}\text { Strength } \\
\text { of } \\
\text { evidence }^{\text {a }}\end{array}$ & Ref \\
\hline & & $\begin{array}{l}\text { High levels of cTn were associated with the severity and } \\
\text { progression of chronic heart failure }\end{array}$ & & [97] \\
\hline & Osteopontin & $\begin{array}{l}\text { High osteopontin levels were associated with left } \\
\text { ventricular dysfunction and reduced levels were correlated } \\
\text { with good response to heart failure therapies }\end{array}$ & + & [98] \\
\hline & ST2 receptor & $\begin{array}{l}\text { High ST2 levels were associated with cardiovascular } \\
\text { mortality in chronic heart failure patients }\end{array}$ & + & [99] \\
\hline & Growth differentiator 15 (GDF-15) & $\begin{array}{l}\text { High GDF-15 levels were associated with risk of developing } \\
\text { CVD and mortality }\end{array}$ & + & [100] \\
\hline
\end{tabular}

$\mathrm{atab}$

hormone with natriuretic, vasodilatory and hypotensive effects [80] and its concentrations were shown to become elevated in chronic HF $[81,82]$. However, since $\mathrm{ADM}$ is unstable in vitro, MR-proADM (mid-regional proadrenomedullin), the precursor of $\mathrm{ADM}$ is quantified instead in clinical laboratories [83]. In the $\mathrm{BACH}$ trial on 1641 patients, MR-proADM identifies patients with high 90 -day mortality risks $[80,84]$. Another emerging HF biomarker is copeptin. Copeptin is a propeptide fragment of arginine vasopressin (AVP), which mediates vasoconstriction and cardiac hypertrophy. Elevated copeptin is significantly linked to 90-day mortality, readmissions, and emergency department visits, especially in those with hyponatremia $[85,86]$. Copeptin was also found to be superior to BNP or N-terminal pro B-type natriuretic peptide (NT-proBNP) as a biomarker for HF; and its increased levels was linked to excess mortality in patients with chronic HF, irrespective of clinical severity [87].

\section{Hemodynamic biomarkers}

During cardiac hemodynamic stress, natriuretic peptides (NP), i.e. BNP or NT-proBNP are secreted. Besides being capable of lowering blood pressure, NPs carry natriuretic, diuretic and kaliuretic properties [88]. NT-proBNP has been reported as an independent risk marker for SCD [61]. This is consistent with another finding that reported an association between higher baseline levels of NTproBNP and SCD over a 16-year follow-up period [89]. BNP was also independently associated with an elevated risk for SCD in patients with chronic HF in the Vienna Heart Failure Cohort [90] and in survivors of acute MI in the Multiple Risk Factor Analysis Trial [91].

\section{Myocardial stress biomarkers}

Tropomyosin interacts with cardiac troponin $(c \operatorname{Tn} C$, $c T n I$ and $c \operatorname{Tn} T)$, forming the troponin-tropomyosin complex that is responsible for cardiac muscle contraction. During myocardial stress, degeneration of the actin and myosin filaments results in the release of cTn into plasma. Therefore, $\mathrm{cTnT}$ and $\mathrm{cTnI}$, being unique to the heart, are specific markers for myocardial damage. Both cTn and high sensitivity cTn (hs-cTn) assays have been used as predictors of mortality in both CAD and HF. For instance, elevated levels of hs-cTn have been associated with $\mathrm{CAD}$ [92]. In a community-based study, elevated cTn was shown to predict death and first CHD event in 1203 elderly men free from CVD at baseline [93]. Whereas, De Lemos et al. demonstrated that elevated levels of hs-cTn were linked with higher adjusted all-cause mortality in the general population [94]. In the PEACE trial, a graded increase in the cumulative incidence of cardiovascular death in those with higher hscTnT levels was observed [95]. On the other hand, as demonstrated by Latini et al., detectable cTnT predicts increased mortality in 4053 patients with chronic HF [96]. Masson et al. also discovered that serial measurements of hs-cTnT concentrations are robust predictors of cardiovascular events in patients with chronic HF [97]. Other noteworthy protein biomarkers that are associated with myocardial stress, necrosis, fibrosis and tissue regeneration are osteopontin (OPN) [98], soluble ST2 receptor [99], and growth differentiator 15 (GDF15) [100]. A list of protein biomarkers and the strength of evidence showing their association with SCD is available in Table 2.

\section{Other molecular biomarkers}

Apart from genes and proteins, metabolites and other small molecules have also been used as molecular biomarkers for SCD. One good example is reported by Jouven et al., who discovered that non-esterified free fatty acids (NEFAs) could be an independent risk factor for SCD [101]. Meanwhile, elevated levels of trans-18:2 fatty acids were associated with higher risk for SCD in an elderly cohort, whereas higher trans-18:1 with lower risk [102]. F2 isoprostanes are prostaglandin compounds that have shown potential as in vivo markers of oxidant injury in cardiovascular pathologies such as 
atherosclerosis and acute coronary syndrome (ACS) $[103,104]$. Asymmetric Dimethylarginine (ADMA) is an endogenous inhibitor of nitric oxide (NO) production and is significantly associated with risk factors for CVD; showing an independent, strong prognostic value for mortality and future cardiovascular events [105].

\section{Challenges and future outlook}

Development of diagnostics for early detection faces immense challenges. For example, although many candidate biomarkers for SCD have been discovered, so far, early biomarkers remain scarce for the relatively concealed group of high-risk individuals who are asymptomatic and this warrants attention. Besides, SCD has very complex pathophysiology and etiology. Therefore, every candidate biomarker needs to be evaluated in larger cohorts, so that SCD risks can be predicted down to specific clinical subgroups [1]. Additionally, most cohort studies have used baseline samples that may be irrelevant to events that occurred years later. Hence, repeat measurements throughout the follow-up period are necessary. For omic-scale studies, extensive statistics assessment is necessary. Even so, mere statistical correlations do not automatically imply clinical usefulness. Therefore, candidates obtained from omic studies should be extensively verified with respect to disease pathophysiology and causality. It is also noteworthy that GWAS results may only explain a small fraction of risks and are often inconsistent. As for proteomics, the analysis of biofluids is still plagued by the high complexity and wide dynamic range of protein concentrations in these sample types. Consequently, depletion, enrichment or fractionation techniques are needed to increase the detection of proteins at low abundances. Despite these hurdles, multimarker panels are increasinlgly applied to provide better discrimination of risks of mortality associated with CAD. Beside the afore-mentioned gene panel that targets 174 expertly-selected genes, it was also demonstrated that the combination of plasma levels of multimarkers such as hs-CRP, HSP70, and fibrin degradation products (FDPs) as a biomarker risk score (BRS) can reliably predict CVD events with elevated levels of all three biomarkers [106].

\section{Conclusion}

$\mathrm{SCD}$ is a fatal disease that has a very complex etiology. Although a number of risk factors and biomarkers have been used for diagnostics, prognostics and risk stratification for SCD, these biomarkers need to be further evaluated with larger and better-defined cohorts. With omic technologies, the discovery process for biomarkers can be accelerated considerably, especially by using the multi-omics strategy that combines genomics, transcriptomics, proteomics and metabolomics [107]. In addition, since SCD manifests complex phenotypes and pathophysiology, the multimarker panel strategy, with the follow-up in other biophysical tests can be a good combination.

\section{Abbreviations}

ASCVD: Atherosclerotic Cardiovascular Diseases; AV: Atrioventricular; BRS: Biomarker Risk Score; CAD: Coronary Artery Disease; CCTA: Coronary Computed Tomography Angiography; CHD: Coronary Heart Disease; CRP: CReactive Protein; CVD: Cardiovascular Disease; ECC: Excitation-Contraction Coupling; ECG: Electrocardiography; FDR: False Discovery Rate;

GWAS: Genome-Wide Association Study; HF: Heart Failure; ICC: Inherited Cardiac Condition; ICD: Implantable Cardioverter Defibrillator; LVEF: Left Ventrivle Ejection Fraction; MACE: Major Adverse Cardiac Event; MI: Myocardial Infaction; RAAS: Renin-Angiotensin Aldosterone System; ROS: Reactive Oxygen Species; SA: Sinoatrial; SCD: Sudden Cardiac Death

\section{Acknowledgements}

We thank the following for financial support. P.Y. Lee and S.C. Tan are respectively supported by the Young Researcher Grants: (i) GGPM-2017-097 and (ii) GGPM-2018-045 awarded by Universiti Kebangsaan Malaysia. T.Y. Low is supported by the Fundamental Research Grant Scheme (FRGS/1/2018/

STG04/UKM/02/7) awarded by the Ministry of Education Malaysia.

\section{Funding}

This study was supported by Arus Perdana Research Grant (AP-2017-007/3) awarded by Universiti Kebangsaan Malaysia to R. Jamal.

\section{Availability of data and materials \\ Not applicable.}

\section{Authors' contributions}

JO and TYL drafted the manuscript and wrote most of the article. SCT and PYL participated in discussion and helped to write the manuscript on genomics and proteomics. RJ oversees the whole project. All authors read and approved the final manuscript.

\section{Ethics approval and consent to participate}

Not applicable.

\section{Consent for publication}

Not applicable.

\section{Competing interests}

The authors declare that they have no competing interests.

\section{Publisher's Note}

Springer Nature remains neutral with regard to jurisdictional claims in published maps and institutional affiliations.

Received: 11 February 2019 Accepted: 16 May 2019

Published online: 22 May 2019

\section{References}

1. Havmoller R, Chugh SS. Plasma Biomarkers for Prediction of Sudden Cardiac Death: Another Piece of the Risk Stratification Puzzle? Circ Arrhythmia Electrophysiol. 2012;5:237-43 Available from: http://www.ncbi.n/m.nih.gov/ pubmed/22334431. [cited 2018 May 25].

2. Fukuda K, Kanazawa H. Aizawa Y, Ardell JL, Shivkumar K. Cardiac Innervation and Sudden Cardiac Death. Circ Res. 2015;116:2005-19.

3. Montagnana M, Lippi G, Franchini M, Targher G, Cesare GG. Sudden cardiac death: prevalence, pathogenesis, and prevention. Ann Med. 2008:40:360-75.

4. Chugh SS. Sudden cardiac death in 2017: spotlight on prediction and prevention. Int J Cardiol. 2017:237:2-5.

5. Empana JP, Boulanger CM, Tafflet M, Renard JM, Leroyer AS, Varenne O, Prugger $C$, et al. Microparticles and sudden cardiac death due to coronary occlusion. The TIDE (Thrombus and inflammation in sudden DEath) study. Eur Hear J Acute Cardiovasc Care. 2015:4:28-36.

6. Stecker EC, Vickers C, Waltz J, Socoteanu C, John BT, Mariani R, et al. Population-based analysis of Sudden Cardiac Death With and without left ventricular systolic dysfunction. J Am Coll Cardiol. 2006;47:1161-6. 
7. Myerburg RJ, Goldberger JJ. Sudden Cardiac Arrest Risk Assessment. JAMA Cardiol. 2017;2:689.

8. Hong J, Barry AR. Long-Term Beta-Blocker Therapy after Myocardial Infarction in the Reperfusion Era: A Systematic Review. Pharmacotherapy. 2018;38(5):546-554.

9. Leibowitz M, Cohen-Stavi C, Basu S, Balicer RD. Targeting LDL Cholesterol: Beyond Absolute Goals Toward Personalized Risk. Curr Cardiol Rep. 2017;19: 52 Available from: http://www.ncbi.nlm.nih.gov/pubmed/28432662. [cited 2018 Oct 22].

10. Arca M, Borghi C, Pontremoli R, De Ferrari GM, Colivicchi F, Desideri G, et al. Hypertriglyceridemia and omega-3 fatty acids: Their often overlooked role in cardiovascular disease prevention. Nutr Metab Cardiovasc Dis. 2018;28: 197-205.

11. Adabag AS, Luepker RV, Roger VL, Gersh BJ. Sudden cardiac death: epidemiology and risk factors. Nat Publ Gr. 2010;7:216-2253.

12. D'Agostino RB Sr, Vasan RS, Pencina MJ, Wolf PA, Cobain M, Massaro JM, Kannel WB. General cardiovascular risk profile for use in primary care: the Framingham Heart Study. Circulation. 2008;117(6):743-53.

13. Thomsen T. HeartScore: a new web-based approach to European cardiovascular disease risk management. Eur J Cardiovasc Prev Rehabil. 2005;12:424-6 Available from: http://www.ncbi.nlm.nih.gov/pubmed/ 16210927. [cited 2018 Oct 21].

14. Reinier K, Narayanan K, Uy-Evanado A, Teodorescu C, Chugh H, Mack WJ, et al. Electrocardiographic markers and left ventricular ejection fraction have cumulative effects on Risk of Sudden Cardiac Death. JACC Clin Electrophysiol. 2015;1:542-50.

15. von Lueder TG, Kotecha D, Atar D, Hopper I. Neurohormonal Blockade in Heart Failure. Card Fail Rev. 2017;03:19 Available from: https://www. cfrjournal.com/articles/neurohormonal-blockade-heart-failure. [cited 2018 Oct 24].

16. Chugh SS, Reinier K, Singh T, Uy-Evanado A, Socoteanu C, Peters D, et al. Determinants of prolonged QT interval and their contribution to sudden death risk in coronary artery disease: the Oregon Sudden Unexpected Death Study. Circulation. 2009;119:663-70 Available from: https://www.ahajournals.org/doi/10.1161/CIRCULATIONAHA.108.797035. [cited 2018 Oct 21]

17. Panikkath R, Reinier K, Uy-Evanado A, Teodorescu C, Hattenhauer J, Mariani $\mathrm{R}$, et al. Prolonged Tpeak-to-Tend Interval on the Resting ECG Is Associated With Increased Risk of Sudden Cardiac Death. Circ Arrhythmia Electrophysiol. 2011;4:441-7 Available from: http://www.ncbi.nlm.nih.gov/ pubmed/21593198. [cited 2018 Oct 21].

18. Montanez A, Ruskin JN, Hebert PR, Lamas GA, Hennekens CH. Prolonged QTC Interval and Risks of Total and Cardiovascular Mortality and Sudden Death in the General Population. Arch Intern Med. 2004;164:943 Available from: http://archinte.jamanetwork.com/article.aspx?doi=10.1001/archinte.164. 9.943. [cited 2018 Oct 22].

19. Low TY, AJR H. Reconciling proteomics with next generation sequencing. Curr Opin Chem Biol. 2016;30:14-20. https://doi.org/10. 1016/j.cbpa.2015.10.023.

20. Strimbu K, Tavel JA. What are biomarkers? Curr Opin HIV AIDS. 2010;5:463-6 Available from: http://www.ncbi.n/m.nih.gov/pubmed/20978388. [cited 2018 Oct 21].

21. Institute of Medicine (US) Forum on Drug Discovery D and T. Qualifying Biomarkers. National Academies Press (US); 2008 [cited 2018 Oct 22]; Available from: https://www.ncbi.nlm.nih.gov/books/NBK4041/

22. Marcsa B, Dénes R, Vörös K, Rácz G, Sasvári-Székely M, Rónai Z, et al. A Common Polymorphism of the Human Cardiac Sodium Channel Alpha Subunit (SCN5A) Gene Is Associated with Sudden Cardiac Death in Chronic Ischemic Heart Disease. PLoS One. 2015;10:e0132137 Available from: http:// dx.plos.org/10.1371/journal.pone.0132137. [cited 2018 Jul 23].

23. Tester DJ, Medeiros-Domingo A, Will ML, Haglund CM, Ackerman MJ. Cardiac channel molecular autopsy: insights from 173 consecutive cases of autopsy-negative sudden unexplained death referred for postmortem genetic testing. Mayo Clin Proc. 2012;87:524-39 Available from: https:// www.mayoclinicproceedings.org/article/S0025-6196(12)00386-2/fulltext. [cited 2018 Jul 23].

24. Bezzina CR, Barc J, Mizusawa Y, Remme CA, Gourraud J-B, Simonet F, et al. Common variants at SCN5A-SCN10A and HEY2 are associated with Brugada syndrome, a rare disease with high risk of sudden cardiac death. Nat Genet. 2013:45:1044-9 Available from: http://www.nature.com/articles/ng.2712. [cited 2018 Jul 23].
25. Ilkhanoff L, Arking DE, Lemaitre RN, Alonso A, Chen LY, Durda P, et al. A common SCN5A variant is associated with PR interval and atrial fibrillation among African Americans. J Cardiovasc Electrophysiol. 2014;25:1150-7 Available from: http://doi.wiley.com/10.1111/jce.12483. [cited 2018 Jul 23].

26. Lahtinen AM, Noseworthy PA, Havulinna AS, Jula A, Karhunen PJ, Kettunen J, et al. Common genetic variants associated with sudden cardiac death: the FinSCDgen study. PLoS One. 2012;7:e41675 Available from: http://dx.plos. org/10.1371/journal.pone.0041675. [cited 2018 Jul 23].

27. Schmitt N, Grunnet M, Olesen S-P. Cardiac Potassium Channel Subtypes: New Roles in Repolarization and Arrhythmia. Physiol Rev. 2014;94:60953 Available from: http://www.ncbi.nlm.nih.gov/pubmed/24692356. [cited 2018 Jul 23].

28. Chiamvimonvat N, Chen-Izu Y, Clancy CE, Deschenes I, Dobrev D, Heijman J, et al. Potassium currents in the heart: functional roles in repolarization, arrhythmia and therapeutics. J Physiol. 2017;595:2229-52 Available from: http://www.ncbi.nlm.nih.gov/pubmed/27808412. [cited 2018 Jul 23].

29. Ali A, Butt N, Sheikh AS. Early repolarization syndrome: A cause of sudden cardiac death. World J Cardiol. 2015;7:466 Available from: http://www.ncbi. nlm.nih.gov/pubmed/26322186. [cited 2018 Jul 23].

30. Winkel BG, Larsen MK, Berge KE, Leren TP, Nissen PH, Olesen MS, et al. The prevalence of mutations in $\mathrm{KCNQ} 1, \mathrm{KCNH} 2$, and SCN5A in an unselected national cohort of young sudden unexplained death cases. J Cardiovasc Electrophysiol. 2012;23:1092-8. https://doi.org/10.1111/j.1540-8167.2012. 02371.x [cited 2018 Jul 23].

31. Lahtinen AM, Havulinna AS, Noseworthy PA, Jula A, Karhunen PJ, Perola M, et al. Prevalence of arrhythmia-associated gene mutations and risk of sudden cardiac death in the Finnish population. Ann Med. 2013;45:328-35. https://doi.org/10.3109/07853890.2013.783995 [cited 2018 Jul 23].

32. Albert CM, MacRae CA, Chasman DI, VanDenburgh M, Buring JE, Manson JE, et al. Common Variants in Cardiac Ion Channel Genes Are Associated With Sudden Cardiac Death. Circ Arrhythmia Electrophysiol. 2010;3:222-9 Available from: http://www.ncbi.nlm.nih.gov/pubmed/ 20400777. [cited 2018 Jul 23].

33. Belevych AE, Radwański PB, Carnes CA, Györke S. "Ryanopathy": causes and manifestations of RyR2 dysfunction in heart failure. Cardiovasc Res. 2013;98: 240-7 Available from: https://academic.oup.com/cardiovascres/article/98/2/ 240/278301. [cited 2018 Jul 23].

34. Calore C, De Bortoli M, Romualdi C, Lorenzon A, Angelini A, Basso C, et al. A founder MYBPC3 mutation results in HCM with a high risk of sudden death after the fourth decade of life. J Med Genet. 2015;52:338-47 Available from: https://jmg.bmj.com/content/52/5/338. [cited 2018 Jul 23].

35. Chen Y-H, Liu J-M, Hsu R-J, Hu S-C, Harn H-J, Chen S-P, et al. Angiotensin converting enzyme DD genotype is associated with acute coronary syndrome severity and sudden cardiac death in Taiwan: a case-control emergency room study. BMC Cardiovasc Disord. 2012;12:6 Available from: http://www.ncbi.nlm.nih.gov/pubmed/22333273. [cited 2018 May 25].

36. Zhao Q, Chen Y, Peng L, Gao R, Liu N, Jiang P, et al. Identification of rare variants of DSP gene in sudden unexplained nocturnal death syndrome in the southern Chinese Han population. Int J Legal Med. 2016;130:317-22 Available from: http://link.springer.com/10.1007/s00414015-1275-2. [cited 2018 Jul 23].

37. Arking DE, Junttila MJ, Goyette P, Huertas-Vazquez A, Eijgelsheim M, Blom MT, et al. Identification of a sudden cardiac death susceptibility locus at 2q24.2 through genome-wide association in European ancestry individuals. PLoS Genet. 2011;7:e1002158 Available from: http://dx.plos.org/10.1371/ journal.pgen.1002158. [cited 2018 Jul 23].

38. Deo R, Albert CM. Epidemiology and Genetics of Sudden Cardiac Death. Circulation. 2012;125:620-37 Available from: http://www.ncbi.nlm.nih.gov/ pubmed/22294707. [cited 2018 Jul 23].

39. Pua CJ, Bhalshankar J, Miao K, Walsh R, John S, Lim SQ, et al. Development of a Comprehensive Sequencing Assay for Inherited Cardiac Condition Genes. J Cardiovasc Transl Res. 2016:9:3-11 Available from: http://www.ncbi. nlm.nih.gov/pubmed/26888179. [cited 2018 Jul 23].

40. Lahrouchi N, Raju H, Lodder EM, Papatheodorou E, Ware JS, Papadakis M, et al. Utility of Post-Mortem Genetic Testing in Cases of Sudden Arrhythmic Death Syndrome. J Am Coll Cardiol. 2017;69:2134-45 Available from: https:// www.sciencedirect.com/science/article/pii/S0735109717359715?via\%3Dihub. [cited 2018 Jul 23].

41. Wang J, Tan G-J, Han L-N, Bai Y-Y, He M, Liu H-B. Novel biomarkers for cardiovascular risk prediction. J Geriatr Cardiol. 2017;14:135-50. 
42. Dhindsa DS, Khambhati J, Sandesara PB, Eapen DJ, Quyyumi AA. Biomarkers to Predict Cardiovascular Death. Card Electrophysiol Clin. 2017;9:651-64 Available from: http://www.ncbi.n/m.nih.gov/pubmed/29173408. [cited 2018 May 25].

43. Zhang X, Sessa WC, Fernández-Hernando C. Endothelial Transcytosis of Lipoproteins in Atherosclerosis. Front Cardiovasc Med. 2018:5:130 Available from: http://www.ncbi.nlm.nih.gov/pubmed/30320124. [cited 2018 Oct 21].

44. Jones DP, Liang Y. Measuring the poise of thiol/disulfide couples in vivo. Free Radic Biol Med. 2009;47:1329-38 Available from: http://www.ncbi.nlm. nih.gov/pubmed/19715755. [cited 2018 Oct 21].

45. Patel RS, Ghasemzadeh N, Eapen DJ, Sher S, Arshad S, Ko Y, et al. Novel Biomarker of Oxidative Stress Is Associated With Risk of Death in Patients With Coronary Artery Disease. Circulation. 2016;133:361-9 Available from: http://www.ncbi.nlm.nih.gov/pubmed/26673559. [cited 2018 Oct 21].

46. Kalmar B, Greensmith L. Induction of heat shock proteins for protection against oxidative stress. Adv Drug Deliv Rev. 2009;61:310-8 Available from: http://www.ncbi.nlm.nih.gov/pubmed/19248813. [cited 2018 Oct 21].

47. Zhu J, Quyyumi AA, Wu H, Csako G, Rott D, Zalles-Ganley A, et al. Increased serum levels of heat shock protein 70 are associated with low risk of coronary artery disease. Arterioscler Thromb Vasc Biol. 2003;23:1055-9 Available from: https://www.ahajournals.org/doi/10.1161/01.ATV.0000074899. 60898.FD. [cited 2018 Oct 21].

48. Eapen DJ, Ghasemzadeh N, MacNamara JP, Quyyumi A. The Evaluation of Novel Biomarkers and the Multiple Biomarker Approach in the Prediction of Cardiovascular Disease. Curr Cardiovasc Risk Rep. 2014;8:408 Available from: http://link.springer.com/10.1007/s12170-014-0408-3. [cited 2018 Oct 21].

49. Shashkin P, Dragulev B, Ley K. Macrophage differentiation to foam cells. Curr Pharm Des. 2005;11:3061-72 Available from: http://www.ncbi.nlm.nih. gov/pubmed/16178764. [cited 2018 Oct 22].

50. Sprague AH, Khalil RA. Inflammatory cytokines in vascular dysfunction and vascular disease. Biochem Pharmacol. 2009;78:539-52 Available from: http:// www.ncbi.nlm.nih.gov/pubmed/19413999. [cited 2018 Oct 22].

51. Empana J-P, Jouven X, Canouï-Poitrine F, Luc G, Tafflet M, Haas B, et al. CReactive Protein, Interleukin 6, Fibrinogen and Risk of Sudden Death in European Middle-Aged Men: The PRIME Study. Arterioscler Thromb Vasc Biol. 2010;30:2047-52 Available from: http://www.ncbi.n/m.nih.gov/pubmed/ 20651278. [cited 2018 Oct 22].

52. Zhao $L$, Wang $X$, Yang $Y$. Association between interleukin- 6 and the risk of cardiac events measured by coronary computed tomography angiography. Int J Cardiovasc Imaging. 2017;33:1237-44 Available from: http://www.ncbi. nlm.nih.gov/pubmed/28233119. [cited 2018 Oct 21].

53. Cainzos-Achirica M, Enjuanes C, Greenland P, McEvoy JW, Cushman M, Dardari Z, et al. The prognostic value of interleukin 6 in multiple chronic diseases and all-cause death: The Multi-Ethnic Study of Atherosclerosis (MESA). Atherosclerosis. 2018;278:217-25 Available from: http://www.ncbi. nlm.nih.gov/pubmed/30312930. [cited 2018 Oct 21].

54. Mahajan K. Interleukin-18 and Atherosclerosis: Mediator or Biomarker. J Clin Exp Cardiolog. 2014;05:1-4 Available from: https://www.omicsonline.org/ open-access/interleukin-and-atherosclerosis-mediator-or-biomarker-21559880-5-352.php?aid=36154. [cited 2018 Oct 21].

55. Opstad TB, Arnesen H, Pettersen Å̊, Seljeflot I. Combined Elevated Levels of the Proinflammatory Cytokines IL-18 and IL-12 Are Associated with Clinical Events in Patients with Coronary Artery Disease: An Observational Study. Metab Syndr Relat Disord. 2016;14:242-8 Available from: http://www.ncbi. nlm.nih.gov/pubmed/27058587. [cited 2018 Oct 21].

56. Yudkin JS, CDA S, Emeis JJ, Coppack SW. C-Reactive Protein in Healthy Subjects: Associations With Obesity, Insulin Resistance, and Endothelial Dysfunction. Arterioscler Thromb Vasc Biol. 1999;19:972-8 Available from: https:/www.ahajournals.org/doi/10.1161/01.ATV.19.4.972. [cited 2018 Oct 22]

57. Bray C, Bell LN, Liang H, Haykal R, Kaiksow F, Mazza JJ, et al. Erythrocyte Sedimentation Rate and C-reactive Protein Measurements and Their Relevance in Clinical Medicine. WMJ. 2016;115:317-21 Available from: http:// www.ncbi.n/m.nih.gov/pubmed/29094869. [cited 2018 Oct 22].

58. Albert CM, Ma J, Rifai N, Stampfer MJ, Ridker PM. Prospective study of Creactive protein, homocysteine, and plasma lipid levels as predictors of sudden cardiac death. Circulation. 2002;105:2595-9.

59. Ridker PM, Danielson E, Fonseca FAH, Genest J, Gotto AM, Kastelein JJP, et al. Rosuvastatin to Prevent Vascular Events in Men and Women with Elevated C-Reactive Protein. N Engl J Med. 2008;359:2195-207 Available from: http://www.nejm.org/doi/abs/10.1056/NEJMoa0807646. [cited 2018 Oct 22]
60. Sobel BE, Hardison RM, Genuth S, Brooks MM, RD MB, Schneider DJ, et al. Profibrinolytic, Antithrombotic, and Antiinflammatory Effects of an InsulinSensitizing Strategy in Patients in the Bypass Angioplasty Revascularization Investigation 2 Diabetes (BARI 2D) Trial. Circulation. 2011;124:695-703 Available from: https://www.ahajournals.org/doi/10.1161/CIRCULATIONAHA. 110.014860. [cited 2018 Oct 22].

61. Korngold EC, Januzzi JL, Gantzer ML, Moorthy MV, Cook NR, Albert CM. Amino-Terminal Pro-B-Type Natriuretic Peptide and High-Sensitivity CReactive Protein as Predictors of Sudden Cardiac Death Among Women. Circulation. 2009;119:2868-76 Available from: http://www.ncbi.nlm.nih.gov/ pubmed/19470888. [cited 2018 Oct 22].

62. Zalewski A, Macphee C. Role of Lipoprotein-Associated Phospholipase $A_{2}$ in Atherosclerosis. Arterioscler Thromb Vasc Biol. 2005;25:923-31 Available from: http://www.ncbi.nlm.nih.gov/pubmed/15731492. [cited 2018 Oct 23].

63. Koenig W, Khuseyinova N, Löwel H, Trischler G, Meisinger C. Lipoprotein-Associated Phospholipase $\mathrm{A}_{2}$ Adds to Risk Prediction of Incident Coronary Events by C-Reactive Protein in Apparently Healthy Middle-Aged Men From the General Population. Circulation. 2004;110: 1903-8 Available from: https://www.ahajournals.org/doi/10.1161/01.CIR. 0000143377.53389.C8. [cited 2018 Oct 23].

64. Daniels LB, Laughlin GA, Sarno MJ, Bettencourt R, Wolfert RL, Barrett-Connor E. Lipoprotein-Associated Phospholipase A2 is an Independent Predictor of Incident Coronary Heart Disease in an Apparently Healthy Older Population: The Rancho Bernardo Study. J Am Coll Cardiol. 2008;51:913-9 Available from: https://www.sciencedirect.com/science/article/pii/S0735109707038090. [cited 2018 Oct 23].

65. Stocker R, Huang A, Jeranian E, Hou JY, Wu TT, Thomas SR, et al. Hypochlorous acid impairs endothelium-derived nitric oxide bioactivity through a superoxide-dependent mechanism. Arterioscler Thromb Vasc Biol. 2004;24:2028-33 Available from: https://www.ahajournals.org/doi/10.1161/ 01.ATV.0000143388.20994.fa. [cited 2018 Oct 23].

66. Teng N, Maghzal GJ, Talib J, Rashid I, Lau AK, Stocker R. The roles of myeloperoxidase in coronary artery disease and its potential implication in plaque rupture. Redox Rep. 2017;22:51-73 Available from: http://www.ncbi. nlm.nih.gov/pubmed/27884085. [cited 2018 Oct 23].

67. Cyrille NB, Villablanca PA, Ramakrishna H. Soluble urokinase plasminogen activation receptor--An emerging new biomarker of cardiovascular disease and critical illness. Ann Card Anaesth. 2016;19:214-6 Available from: http:// www.ncbi.nlm.nih.gov/pubmed/27052059. [cited 2018 Oct 23].

68. Hodges GW, Bang CN, Wachtell K, Eugen-Olsen J, Jeppesen JL. suPAR: A New Biomarker for Cardiovascular Disease? Can J Cardiol. 2015;31:1293-302 Available from: http://www.ncbi.nlm.nih.gov/pubmed/26118447. [cited 2018 Oct 23].

69. Lyngbæk S, Marott JL, Sehestedt T, Hansen TW, Olsen MH, Andersen O, et al. Cardiovascular risk prediction in the general population with use of suPAR, CRP, and Framingham Risk Score. Int J Cardiol. 2013;167:2904-11 Available from: http://www.ncbi.nlm.nih.gov/pubmed/22909410. [cited 2018 Oct 23]

70. Garlanda C, Bottazzi B, Bastone A, Mantovani A. Pentraxins at the crossroads between innate immunity, inflammation, matrix deposition, and female fertility. Annu Rev Immunol. 2005;23:337-66 Available from: http://www.annualreviews. org/doi/10.1146/annurev.immunol.23.021704.115756. [cited 2018 Oct 27].

71. Guo T, Huang L, Liu C, Shan S, Li Q, Ke L, et al. The clinical value of inflammatory biomarkers in coronary artery disease: PTX3 as a new inflammatory marker. Exp Gerontol. 2017;97:64-7 Available from: http:// www.ncbi.nlm.nih.gov/pubmed/28778748. [cited 2018 Oct 21].

72. Latini R, Gullestad L, Masson S, Nymo SH, Ueland T, Cuccovillo I, et al. Pentraxin-3 in chronic heart failure: the CORONA and GISSI-HF trials. Eur J Heart Fail. 2012;14:992-9 Available from: http://www.ncbi.nlm.nih.gov/ pubmed/22740508. [cited 2018 Oct 26].

73. Watanabe N, Ikeda U, et al. Curr Atheroscler Rep. 2004;6:112-20 Available from: http://www.ncbi.n/m.nih.gov/pubmed/15023295. [cited 2018 Oct 23].

74. Kai H, Ikeda H, Yasukawa H, Kai M, Seki Y, Kuwahara F, et al. Peripheral blood levels of matrix metalloproteases-2 and -9 are elevated in patients with acute coronary syndromes. J Am Coll Cardiol. 1998;32:368-72 Available from: http://www.ncbi.n/m.nih.gov/pubmed/9708462. [cited 2018 Oct 23].

75. Alberto P, Francesca I, Chiara S, Ranuccio N. Acute coronary syndromes: from the laboratory markers to the coronary vessels. Biomark Insights. 2007; 1:123-30 Available from: http://www.ncbi.nlm.nih.gov/pubmed/19690642. [cited 2018 Oct 23].

76. Hartupee J, Mann DL. Neurohormonal activation in heart failure with reduced ejection fraction. Nat Rev Cardiol. 2017;14:30-8 Available from: http://www.ncbi.nlm.nih.gov/pubmed/27708278. [cited 2018 Oct 24]. 
77. Tomaschitz A, Pilz S, Ritz E, Morganti A, Grammer T, Amrein K, et al. Associations of plasma renin with 10-year cardiovascular mortality, sudden cardiac death, and death due to heart failure. Eur Heart J. 2011;32:2642-9 Available from: https://academic.oup.com/eurheartj/article/32/21/2642/ 439190. [cited 2018 Oct 24].

78. Tomaschitz A, Pilz S, Ritz E, Meinitzer A, Boehm BO, Marz W. Plasma aldosterone levels are associated with increased cardiovascular mortality: the Ludwigshafen Risk and Cardiovascular Health (LURIC) study. Eur Heart J. 2010;31:1237-47 Available from: https://academic.oup.com/eurheartj/article/ 31/10/1237/487424. [cited 2018 Oct 24].

79. Beygui F, Collet J-P, Benoliel J-J, Vignolles N, Dumaine R, Barthélémy O, et al. High Plasma Aldosterone Levels on Admission Are Associated With Death in Patients Presenting With Acute ST-Elevation Myocardial Infarction. Circulation. 2006;114:2604-10 Available from: https://www.ahajournals.org/ doi/10.1161/CIRCULATIONAHA.106.634626. [cited 2018 Oct 24].

80. Peacock WF. Novel biomarkers in acute heart failure: MR-proadrenomedullin. Clin Chem Lab Med. 2014;52:1433-5 Available from: http:// www.ncbi.n/m.nih.gov/pubmed/24756062. [cited 2018 Oct 24].

81. Jougasaki M, Rodeheffer RJ, Redfield MM, Yamamoto K, Wei CM, McKinley $\sqcup$, et al. Cardiac secretion of adrenomedullin in human heart failure. J Clin Invest. 1996;97:2370-6 Available from: http://www.ncbi.nlm.nih.gov/ pubmed/8636418. [cited 2018 Oct 24]

82. Nishikimi T, Saito Y, Kitamura K, Ishimitsu T, Eto T, Kangawa K, et al. Increased plasma levels of adrenomedullin in patients with heart failure. J Am Coll Cardiol. 1995;26:1424-31 Available from: https://www.sciencedirect. com/science/article/pii/073510979500338X?via\%3Dihub. [cited 2018 Oct 24].

83. Morgenthaler NG, Struck J, Alonso C, Bergmann A. Measurement of Midregional Proadrenomedullin in Plasma with an Immunoluminometric Assay. Clin Chem. 2005;51:1823-9 Available from: http://www.ncbi.nlm.nih. gov/pubmed/16099941. [cited 2018 Oct 24].

84. Maisel A, Mueller C, Nowak R, Peacock WF, Landsberg JW, Ponikowski P, et al. Mid-Region Pro-Hormone Markers for Diagnosis and Prognosis in Acute Dyspnea: Results From the BACH (Biomarkers in Acute Heart Failure) Trial. J Am Coll Cardiol. 2010;55:2062-76 Available from: https:/www.sciencedirect.com/ science/article/pii/S0735109710009976. [cited 2018 Oct 24].

85. Balling L, Gustafsson F. Copeptin as a biomarker in heart failure. Biomark Med. 2014;8:841-54 Available from: http://www.ncbi.nlm.nih.gov/pubmed/ 25224940. [cited 2018 Oct 24].

86. Maisel A, Xue Y, Shah K, Mueller C, Nowak R, Peacock WF, et al. Increased 90Day Mortality in Patients With Acute Heart Failure With Elevated Copeptin. Circ Hear Fail. 2011;4:613-20 Available from: https://www.ahajournals.org/doi/10. 1161/CIRCHEARTFAILURE.110.960096. [cited 2018 Oct 24].

87. Neuhold S, Huelsmann M, Strunk G, Stoiser B, Struck J, Morgenthaler NG, Bergmann A, Moertl D, Berger R, Pacher R. Comparison of copeptin, B-type natriuretic peptide, and amino-terminal pro-B-type natriuretic peptide in patients with chronic heart failure: prediction of death at different stages of the disease. J Am Coll Cardiol. 2008;52(4):266-72.

88. Pandit K, Mukhopadhyay P, Ghosh S, Chowdhury S. Natriuretic peptides: Diagnostic and therapeutic use. Indian J Endocrinol Metab. 2011;15 Suppl 4: S345-53 Available from: http://www.ncbi.n/m.nih.gov/pubmed/22145138. [cited 2018 Oct 24].

89. Patton KK, Sotoodehnia N, DeFilippi C, Siscovick DS, Gottdiener JS, Kronmal RA. N-terminal pro-B-type natriuretic peptide is associated with sudden cardiac death risk: the Cardiovascular Health Study. Heart Rhythm. 2011;8(2):228-33.

90. Berger R, Huelsman M, Strecker K, Bojic A, Moser P, Stanek B, et al. B-Type Natriuretic Peptide Predicts Sudden Death in Patients With Chronic Heart Failure. Circulation. 2002;105:2392-7 Available from: https:/www.ahajournals. org/doi/10.1161/01.CIR.0000016642.15031.34. [cited 2018 Oct 24].

91. Cohn JN, Tognoni G. A Randomized Trial of the Angiotensin-Receptor Blocker Valsartan in Chronic Heart Failure. N Engl J Med. 2001;345:1667-75 Available from: http://www.nejm.org/doi/abs/10.1056/NEJMoa010713. [cited 2018 Oct 24].

92. Everett BM, Brooks MM, HEA V, Chaitman BR, Frye RL, Bhatt DL. Troponin and Cardiac Events in Stable Ischemic Heart Disease and Diabetes. N Engl J Med. 2015;373:610-20 Available from: http://www.nejm.org/doi/10.1056/ NEJMoa1415921. [cited 2018 Oct 25].

93. Zethelius $B$, Johnston N, Venge P. Troponin I as a Predictor of Coronary Heart Disease and Mortality in 70-Year-Old Men. Circulation. 2006;113:10718 Available from: https://www.ahajournals.org/doi/10.1161/ CIRCULATIONAHA.105.570762. [cited 2018 Oct 25].
94. de Lemos JA, Drazner MH, Omland T, Ayers CR, Khera A, Rohatgi A, et al. Association of Troponin T Detected With a Highly Sensitive Assay and Cardiac Structure and Mortality Risk in the General Population. JAMA. 2010; 304:2503 Available from: https://jamanetwork.com/journals/jama/fullarticle/ 187038. [cited 2018 Oct 25].

95. Omland T, de Lemos JA, Sabatine MS, Christophi CA, Rice MM, Jablonski KA, et al. A Sensitive Cardiac Troponin T Assay in Stable Coronary Artery Disease. N Engl J Med. 2009;361:2538-47 Available from: http://www.nejm. org/doi/abs/10.1056/NEJMoa0805299. [cited 2018 Oct 25].

96. Latini R, Masson S, Anand IS, Missov E, Carlson M, Vago T, et al. Prognostic Value of Very Low Plasma Concentrations of Troponin T in Patients With Stable Chronic Heart Failure. Circulation. 2007;116:1242-9 Available from: https://www.ahajournals.org/doi/10.1161/CIRCULATIONAHA.106.655076. [cited 2018 Oct 25].

97. Masson S, Anand I, Favero C, Barlera S, Vago T, Bertocchi F, et al. Serial Measurement of Cardiac Troponin T Using a Highly Sensitive Assay in Patients With Chronic Heart Failure. Circulation. 2012;125:280-8 Available from: https://www.ahajournals.org/doi/10.1161/CIRCULATIONAHA.111. 044149. [cited 2018 Oct 25].

98. Francia P, Balla C, Ricotta A, Uccellini A, Frattari A, Modestino A, et al. Plasma osteopontin reveals left ventricular reverse remodelling following cardiac resynchronization therapy in heart failure. Int J Cardiol. 2011;153:306-10 Available from: http://www.ncbi.nlm.nih.gov/pubmed/20863582. [cited 2018 Oct 27].

99. Bayes-Genis A, de Antonio M, Vila J, Peñafiel J, Galán A, Barallat J, et al. Head-to-Head Comparison of 2 Myocardial Fibrosis Biomarkers for LongTerm Heart Failure Risk Stratification: ST2 Versus Galectin-3. J Am Coll Cardiol. 2014;63:158-66 Available from: https://www.sciencedirect.com/ science/article/pii/S0735109713051504. [cited 2018 Oct 27].

100. Anand I, McMurray JJV, Whitmore J, Warren M, Pham A, McCamish MA, et al. Anemia and Its Relationship to Clinical Outcome in Heart Failure. Circulation. 2004;110:149-54 Available from: http://www.ncbi.nlm.nih.gov/ pubmed/15210591. [cited 2018 Oct 27].

101. Jouven $X$, Charles MA, Desnos $M$, Ducimetière $P$. Circulating nonesterified fatty acid level as a predictive risk factor for sudden death in the population. Circulation. 2001;104:756-61 Available from: http://www.ncbi. nlm.nih.gov/pubmed/11502698. [cited 2018 Oct 27].

102. Lemaitre RN, King IB, Mozaffarian D, Sotoodehnia N, Rea TD, Kuller LH, et al. Plasma phospholipid trans fatty acids, fatal ischemic heart disease, and sudden cardiac death in older adults: the cardiovascular health study. Circulation. 2006;114:209-15 Available from: https://www.ahajournals.org/ doi/10.1161/CIRCULATIONAHA.106.620336. [cited 2018 Oct 27].

103. Milne GL, Musiek ES, Morrow JD. F 2 -Isoprostanes as markers of oxidative stress in vivo: An overview. Biomarkers. 2005;10:10-23 Available from: http://www.ncbi.nlm.nih.gov/pubmed/16298907. [cited 2018 Oct 27].

104. LeLeiko RM, Vaccari CS, Sola S, Merchant N, Nagamia SH, Thoenes M, et al. Usefulness of Elevations in Serum Choline and Free F2-Isoprostane to Predict 30-Day Cardiovascular Outcomes in Patients With Acute Coronary Syndrome. Am J Cardiol. 2009;104:638-43 Available from: http://www.ncbi. nlm.nih.gov/pubmed/19699337. [cited 2018 Oct 27].

105. Bouras G, Deftereos S, Tousoulis D, Giannopoulos G, Chatzis G, Tsounis D, et al. Asymmetric Dimethylarginine (ADMA): a promising biomarker for cardiovascular disease? Curr Top Med Chem. 2013;13:180-200 Available from: http://www.ncbi.nlm.nih.gov/pubmed/23470077. [cited 2018 Oct 27].

106. Ghasemzadeh N, Hayek SS, Ko Y-A, Eapen DJ, Patel RS, Manocha P, et al. Pathway-Specific Aggregate Biomarker Risk Score Is Associated With Burden of Coronary Artery Disease and Predicts Near-Term Risk of Myocardial Infarction and Death. Circ Cardiovasc Qual Outcomes. 2017;10 Available from: https://www.ahajournals.org/doi/10.1161/CIRCOUTCOMES.115.001493. [cited 2018 Oct 28].

107. Lee PY, Chin S-F, Low TY, Jamal R. Probing the colorectal cancer proteome for biomarkers: Current status and perspectives. J Proteomics. 2018;187:93105 Available from: http://www.ncbi.n/m.nih.gov/pubmed/29953962. [cited 2018 Sep 10]. 